\title{
THE PROBLEM OF LEGAL REGULATION OF THE OPERATION OF THE OVER-THE-COUNTER (OTC) CURRENCY MARKET (FOREX) IN UKRAINE AND THE EU
}

\author{
Eugene Podorozhnyi' \\ Kharkiv National University of Internal Affairs, Ukraine \\ Dmytro Sirokha² \\ Taras Shevchenko National University of Kyiv, Ukraine \\ Pavlo Komirchyi ${ }^{3}$ \\ National Academy of Internal Affairs of Ukraine, Ukraine
}

\begin{abstract}
The aim of the article is to evaluate the state of legal institutionalization of the OTC foreign exchange market in Ukraine, as well as its comparison with the foreign experience of legal regulation of OTC currency relations in Ukraine and EU countries. The subject of the study is the legal and administrative framework for the functioning of the OTC currency market (Forex) in Ukraine and in the EU countries. The methodology of the study consists of: historical and legal method, which allowed determining the preconditions for the emergence of OTC markets in Ukraine and the world and the principles of their functioning; system and structural method, which was used to analyse the world monetary system as an institutional and functional form of organization of international monetary and financial relations; a formal legal method that allowed us to comprehensively investigate a condition of regulation of the functioning of Forex in Ukraine, to identify its shortcomings, gaps, contradictions, and miscalculations, as well as to develop recommendations aimed at their elimination; a comparative and legal method that provided a deeper study of the specifics of the legal regulation of the functioning of Forex in the EU and to define ways of implementing a positive foreign experience in the national legal system. The results of the conducted legal study have shown that in Ukraine, the Forex market operates in legal vacuum conditions that negatively affect either the protection of the rights of forex clients or the amount of tax revenues to the state budget. The most acceptable way to eliminate this shortcoming is to implement the main principles and requirements of the MiFID in the national legislation. Practical impact. The research of experience of EU countries regarding the legal regulation of Forex companies activity and also regarding the creation of legal bases for implementation by the specified companies of self-regulation - it is a necessary condition of further improvement of the legal regulation of the OTC currency relations in Ukraine. Correlation/Authenticity. The mentioned directions of improvement of domestic legislation in the field of the functioning of the OTC currency market (Forex) are the most promising at the modern stage of development of the domestic economy. It is so because they are aimed at ensuring stability, reliability, and efficiency of the financial system, strengthening the guarantees of the rights of private investors, and increasing tax revenues from the activities of forex companies.
\end{abstract}

Key words: currency market, currency system, forex, forex trading company.

JEL Classification: A11, B17

\section{The statement of the problem}

The weakness of its financial system is one of the most important issues for modern Ukraine. It does not ensure the normal functioning and stable development of the domestic economy. This situation negatively affects the competitiveness of our country, which is an extremely important moment of Ukraine's participation in a number of globalization and integration processes. Particularly, it constrains rates of its join to a highly developed European community as a full member. A number of Ukrainian researchers have repeatedly emphasized the importance of the issue of ensuring

\footnotetext{
Corresponding author:

${ }^{1}$ Department of Labor and Commercial Law, Kharkiv National University of Internal Affairs.

2 Department of labor law and social security law, Taras Shevchenko National University of Kyiv.

3 Department of Management and Human Resources, National Academy of Internal Affairs of Ukraine.
} 
the stability, reliability, and efficiency of the financial system as a guarantee of the proper development of the national economy. At the same time, most of them pay attention to the fact that the current financial system of Ukraine has many significant problems and disadvantages, which determines the need to improve approaches to the organization and implementation of public administration. For example, such scientists as N. Ye. Seliuchenko and Z. Shmihelska quite rightly point out that the formation of a system of financial bodies and institutions in Ukraine today is extremely relevant, because the efficiency of the functioning of state bodies and the stability of the development of the country's economy, in general, depends on the correct solution of this issue. Therefore, it is important to improve the financial system of Ukraine, which is still on the stage of formation and it really needs control from the authorities of the country. Besides, the correct financial model will not only stimulate the manufacturer but will also ensure the effectiveness of financial relations in society (Seliuchenko, Shmihelska, 2012). V.F. Rol, V.V. Serhiienko, and S. Popova write in their researches that problems of regulation of financial relations are among the most urgent for the modern stage of development of Ukraine. Finances are the material basis of the existence of the state, a source of monetary support for its functions. Therefore, it seeks to regulate in details the social relations that arise during formation, distribution and use of various funds of funds (Rol, Serhiienko, Popova, 2011). Lawyers point out that in countries with a developed market economy, finance is the main economic tool for influencing the processes of expanded reproduction, distribution, and redistribution of the aggregate social product (Rol, Serhiienko, Popova, 2011). P. Ya. Kravchuk and Yu. S. Tkachuk point out that innovative development of society is possible only in case of presence of a powerful financial system. In Ukraine, the financial system does not yet solve complex economic and social problems. That is why the creation of the efficient financial system requires new scientific research, a deep analysis of causes and consequences of the creation and use of financial resources funds (Kravchuk, 2013). V. Chernenko emphasizes that problems of stabilization and improvement of the financial system of Ukraine are the most urgent issues for the state. The aim of stabilization is to create real starting conditions for the structural adjustment of the economy, the restoration of the investment process, and the mobilization of the relevant financial resources through the formation of the financial market and other financial institutions (Chernenko).

\section{The condition of research}

One of the significant gaps in the government's management of the domestic financial system is the lack of qualitative regulation of the functioning of the Forex market in Ukraine. Such scientists as: A. Paskalova, V. Holubchik, Y. Sibirianska, Ye. Virlych, L. Maliarchuk, P. Pirnykoza, S. Dziuba paid attention in their researches to the relevance of this issue and to the need for its constructive solution. In the context of Ukraine's course to European integration, the issue of regulating the Forex market in our country becomes especially important, because in the territory of the EU functioning of this market takes place in a clearly defined legal field. That is why in this article we would like to consider the state of legal institutionalization of Forex in Ukraine, as well as we will compare it with foreign (especially in the EU) experience of legal regulation of this currency market.

\section{Statement of the basic material}

The foreign exchange market of Ukraine, as well as currency markets of the majority of countries of the world, substantially reflects the state of the economy of the country. Foreign exchange market acts as the objective organizer of the currency relations, which segments and orders aspiration of different economic agents. The latest events in the world show importance of the influence of the foreign exchange market on the economy. The development of the crisis has shown how closely are connected the monetary and financial spheres and under a certain coincidence, what extent of their impact on the main fields of economic activity and financial security in general (Korol, 2015) can be. On the pages of special literature, depending on the context, the currency market is determined differently. Thus, the economic category (the currency market) is a system of stable economic and organizational relations related to the operations of purchase and sale of foreign and payment documents in foreign currencies. As an institutional mechanism, it is a set of institutions and organizations - TNB, currency exchanges, brokerage firms, which ensure the functioning of foreign exchange market mechanisms (Bozhydarnik, 2013). From the financial and legal point of view, the currency market is a set of social relations between authorized entities that are regulated by the law of a state, that arises in the financial sphere of the state and it is related to the implementation of activities aimed at the possession, use, and disposal of financial instruments in foreign currency or currency valuables (Starynskyy, 2012).

Foreign exchange markets in the modern sense were formed in the XIX century. This was facilitated by the following prerequisites:

- development of international economic relations; - creation of a world monetary system that imposes certain obligations on member countries with respect to their national currency systems;

- broad use of international payments;

- strengthening concentration and centralization of bank capital, development of correspondent relations between banks of different countries, spreading the 
practice of maintaining current correspondent accounts in foreign currency;

- improvement of communication facilities - telegraph, telephone, telex, which facilitated contacts between foreign exchange markets and reduced the degree of currency and credit risks;

- development of information technology, rapid transmission of communications about exchange rates, banks, the status of their correspondent accounts, tendencies in the economy and policy (Bozhydarnik, 2013).

The world monetary system is an institutional and functional form of the organization of international monetary and financial relations that has developed as a result of the evolution of the world economy and it is legally enshrined by the intergovernmental agreements. The main task of this system is to regulate international settlements and foreign exchange markets, mediate payments for exports and imports of goods, capital, services, and other types of international economic activity, create favourable conditions for the development of production and the international division of labour. This dynamic, evolutionary system has gone a series of stages in its development, each of which reflects the level of maturity of monetary and financial relations and their institutions (Rohach, Filipenko, Shemet, 2003).

The first in the history of the world monetary system was a system, which was based on the uniform rules of circulation of golden money goods and it is known under the name of the system of "gold standard". The beginning of the gold standard was made by the Bank of England in 1821. Legally, this currency system was issued at the conference in Paris in 1867. The system of the gold standard was characterized by the fact that the role of a universal equivalent was fixed to gold, and gold coins or bank notes, the exchange of gold were in circulation.

The system of the gold standard has become widespread in the world in the last quarter of the 19th century: in Germany in 1871-1873, in France from 1878, and in Japan in 1897 (Patyka, 2012).

The golden standard system was based on several simple principles:

- Countries fix the golden content of national currency units; currency parities are determined by the ratio of the golden weight of currencies;

- Countries provide the convertibility of national currencies to gold; therefore, they bind volumes of the monetary offer with volumes of the gold reserves;

- Gold is freely exported and imported. The gold standard provided the stability of exchange rates. Deviations from the golden parity were not big and were limited by "golden points" - economic boundaries, which were determined by the amount of expenses for the export of gold abroad for exchange for any currency (transportation, insurance, packing, unloading costs, etc.). The gold standard also provided a long-term balance of payments balances (Hrontkovska, Riaba, Ventsuryk, Krasnovska, 2014).

The Second World War actually destroyed the system of gold-digging standard, which prompted the development of a monetary and financial system that was adequate to new conditions of the functioning of the world economy and international economic relations. After long preparatory work, such a system has been created and institutionally issued in 1944 (Rohach, Filipenko, Shemet, 2003). This year, by the initiative of the US in the American city of Bretton Woods, an international monetary and financial conference was convened by the 44 states that signed the charter of the SOA, including the USSR. The subjects of discussion were two projects of the new international monetary order - English, created by J.M. Keynes, and the American one - proposed by $H$. White. The Keynesian project differed by the scale of the proposed reforms and the European vector of change. In this project, it was written about creation of an institutional basis of the international cooperation systems of the international organizations (The World Bank of the central banks, International Clearing Union, International Investment Bank, organizations for environmental regulation, International Bank for Reconstruction and Development, etc.), which are able to regulate and concentrate resources that will help to avoid the dangers of economic downturns and, above all, will reduce the burden of external constraints on the devastated European economy by giving it the financial resources needed to rebuild and develop (Hrontkovska, Riaba, Ventsuryk, Krasnovska, 2014). As H. E. Hrontkovska, O. I. Riaba, A. M. Ventsuryk point out, plan of $\mathrm{H}$. White was simpler, more pragmatic, and pro-American. Institutional terms were proposed only for creating a stabilization fund - it is a simple common cash from the deposits of participating countries and it was excluded the possibility of creating a world power that could create competition for American economic and political leadership. At the same time, as the researchers emphasize, two projects also had common ideas: the recognition of the need for freedom of world trade and financial exchange, international monetary stability and the achievement of balance of payments, replacing the gold standard with gold, the creation of an international organization to oversee the functioning of the world monetary system, mutual cooperation and settlement of balance of payments. The agreements signed in Bretton Woods were really close to $\mathrm{H}$. White's project (Hrontkovska, Riaba, Ventsuryk, Krasnovska, 2014).

Yu. H. Kozak, K. I. Rzhepishevskyi, V. V. Kovalevskyi and others note that the Bretton Woods Agreement has become an important stage in the development of the international monetary system. As for the first time the currency system began to be based on the 
interstate agreement, which establishes common rules for all and establishes such international organization as the International Monetary Fund (IMF) - which "obligation" is to ensure normal functioning of system and compliance principles established by the general agreement (Kozak, Rzhepishevskyi, Kovalevskyi, 2004). The IMF Statute has defined the basic principles of the new currency system. The Bretton Woods currency system functioned until the middle of the 70th years of the 20th century and has played a significant role in deepening of the international division of labour, production internationalization, and in the intensive development of foreign economic relations (Rohach, Filipenko, Shemet, 2003). However, with the growth of the global economy, with the increased competition, the growth of inflation, a sharp increase in financial transactions not related to specific foreign trade agreements, as well as in connection with the crisis of the key currency system - the US dollar, the Bretton Woods monetary system satisfied more less all the needs of international trade and capital movements (Kozak, Rzhepishevskyi, Kovalevskyi, 2004).

In connection with this, we have a question about the introduction of a new international monetary system that would correspond to the realities of world modern economic life. That is why in 1971 when the decision of the President of the USA cancelled the convertibility of the dollar into gold, The Bretton Woods Monetary System has stopped to exist - instead of it a floating exchange rate was introduced, i.e. a market valuation system. Since 1974, all leading currencies (such as the dollar, pound sterling, German mark, yen, French franc) were already free to swim in relation to each other. In the same year, "Special Drawing Right" - "SDR basket" became the new standard of the value of currencies. In 1976, the IMF decided to refuse to fix the official price of gold, by stopping operations with him within the framework of the IMF, giving the national currency bodies the right to dispose of their own gold at their discretion. Finally, in 1978, the IMF's statute secured a refusal from the fixed parities and a new currency system (Hrontkovska, Riaba, Ventsuryk, Krasnovska, 2014), which was named Jamaica, was officially put into effect, because the amendments to the IMF Statute were made by the international agreement, which was signed in January 1976 in Kingston (Jamaica).

And during this period, the Forex market appeared on the world financial and monetary stage - it is the interbank market, which operates around the clock and has no links to any stock exchange. The term "FOREX" in English means "foreign exchange". Terms of trade in this currency market are the same for its participants, the key principle of its operation is free trade, the ability to buy and sell currency at the most favourable price, which depends on demand and supply on it.

For a long time, the market Forex was available only to banks and to the international corporations. For example, $80 \%$ of the total profits of the largest Swiss bank Union Bank of Switzerland (UBS) in 1994 have made operations in the foreign exchange market, and only $20 \%$ of total profit - income from the credits and trade in securities (Chto takoe Foreks). However, in the second half of the 90 s of the twentieth century, currency brokers began to function, which allowed "small" participants, particularly, ordinary citizens, to enter this market in order to earn a difference in exchange rates. The active development of information and communication technologies and the aggressive advertising company, which was aimed at attracting investors - all these factors have contributed to the active development of the Forex market and increased volumes of currency transactions on it. Over the past three decades, the Forex currency market has developed into the largest financial market in the world, whose turnover was about $\$ 4$ trillion a day, according to a 2010 study published by the Bank for International Settlements. The main currencies in this market are the US dollar (USD), Euro (EUR), Japanese yen (JPY), Swiss franc (CHF) and British pound sterling (GBP) [Chto takoe Foreks]. In 2016, the daily volume of transactions in the Forex market amounted to 5.1 trillion dollars in the structure of operations in the Forex market, foreign exchange swaps (on average $47 \%$ ), operational spots (on average 33\%) and forward transactions (13-14\%) occupy the largest share, and among the major Forex currency currencies are the US dollar, the euro, the Japanese yen, the British pound sterling. The highest levels of monetary turnover have currency pairs of euro/dollar, US dollar/Japanese yen ( $23 \%$ and $18 \%$ of all transactions in 2016, respectively) (Paskalova, Sibirianska, Maliarchuk, Pirnykoza, 2017). From the mentioned information it is clear that the volumes of this market are spectacular, and according to forecasts of various financial and analytical organizations (by 2020 the size of daily operations on Forex can grow from 10 to 20 trillion dollars a day).

Participants of the foreign exchange market are banks, international corporations and export-import companies, investment funds, as well as private investors. Millions of people around the world conduct trading on the Forex market and earn a profit by fluctuating foreign exchange rates. Forex operations today are one of the main sources of income for banks and financial institutions around the world. The current Forex market is the only telecommunication network of interconnected banks and other financial institution that does not have a territorially defined place of trade and temporary restrictions, auctions can start on Monday morning in New Zealand and can close on Friday evening in the United States. A participant of the foreign exchange market can become anyone, regardless of the location, because, for transactions in the Forex market, it is necessary only to have access to the Internet and the necessary knowledge (Chto takoe Foreks). 
In our country, the studied currency market, that is, Forex appeared in the late 90 s of the twentieth century with the beginning of the development of free market relations. And firstly, as in other countries, it was a technology that operated exclusively within some banks. Moreover, the use of such technology was possible only in those banks that were able to operate with sufficiently large funds outside of the NBU's foreign exchange supervision. Thus, citizens of Ukraine had to get acquainted with Forex exclusively through the representative offices of foreign dealerships (Holubchik, 2012). However, in the end, ordinary citizens received access to this market.

Extremely high level of liquidity of the Forex market; opportunity, due to the existence of a leverage to carry out operations in the presence of a participant in the market of a monetary amount much less than what is needed; an extremely high level of potential profitability; freedom to carry out transactions; round-the-clock and global availability has helped to gain a high popularity of this market among private investors. According to the research of the Association "Ukrainian Centre for the Development of OTC Financial Instruments and Technologies" in 2012, the volume of annual revenues to the accounts of Ukrainian participants in the Forex market made to 40 million dollars. The total number of Ukrainians, who are actively engaged in transactions on Forex, has exceeded over 70 thousand people. In this case, they use services of more than 30 operators (Obsyahy rynku forex v Ukrayini syahayut $40 \mathrm{mln}$ dolariv; Vyhody ta ryzyky instytualizatsiyi rynku Foreks vUkrayini). In 2015-2016, the number of clients of forex brokers in Ukraine was about 100 thousand people, and the amount of funds invested by the latter amounted to about 200 million dollars. Although these data are approximate, at the same time they clearly indicate that, even despite the economic crisis in Ukraine, the real interest of the population in the Forex is growing. That is quite clear, considering it mentioned features (liquidity, availability, high potential profitability, ubiquity, relative ease (from a technical point of view), work on it, etc.).

Taking into account the scale of this market, it is obvious that it cannot be left out of the state's attention. However, this sector has not yet received a proper legal regulation in Ukraine. It negatively affects either the rights of forex brokers or profits of the state itself. According to the research, over the lack of regulation of such companies by the state, in the shadow of the Ukrainian forex market annually rotate about 200 million USD (Paskalova, Sibirianska, Maliarchuk, Pirnykoza, 2017). Of course, we cannot say that there is no legal framework for the functioning of the Forex market in Ukraine, its certain aspects are regulated by provisions of the Civil and Tax Codes of Ukraine, Laws "On Banks and Banking" on 7.12. 2000 No. 2121III, "On National Bank of Ukraine" dated 20.05.1999 № 679-XIV, “On Procedure for Settlement in Foreign
Currency” on 23.09.1994 № 185/94-VR, Resolution of the Board of the National Bank of Ukraine "On Approval of Instruction on Procedure for Opening, Use, and Closure of Accounts in the National and Foreign Currency” of November 12, 2003 No. 492, "On Amendments to Certain Regulatory Acts of the National Bank of Ukraine” on 3.08.2012 № 327 and others. However, the provisions of these and other regulatory documents regulate the investigated industry only partly.

The lack of a legal field has led to the emergence and active growth of unfair forex brokers (the so-called "kitchens") in the first decade of the 21 st century, which, by carrying out aggressive advertising companies, attracted a huge amount of funds from private investors, and in a few years was recognized as a bankrupt. Trying to protect somehow citizens against similar fraudulent, to provide reliability, legality, and controllability of operations in the Forex market, the NBU has adopted the Resolution "On Introduction of Amendments to Some Normative Legal Acts of the National Bank of Ukraine" on 3:08.2012 No. 327. According to this legal regulation and the Regulation of Procedure and Conditions for Trade in Foreign Currency on August 10, 2005, No. 281, Ukrainian investors may invest in the Forex market only through authorized banks. Particularly, this Resolution stipulates that authorized banks have the right to conduct their own arbitration operations and arbitration operations on behalf of clients with foreign counterparties. Authorized banks have the right to conduct arbitration operations with foreign banks and/or foreign nonbank financial institutions, if such an institution has the right to trade in foreign currency in correspondence with the law of the country, where it is registered, and it is covered by the supervisory activities of the corresponding bodies of supervision of the financial institutions of foreign countries. Authorized banks have the right to carry out arbitration operations on the basis of the contracts signed with such clients as: physical resident persons; legal entities, which are not authorized banks, and individuals - subjects of entrepreneurial activity; other authorized banks. Authorized banks have the right to carry out arbitration operations only after the registration in the National Bank of rules for conducting these operations in the order, which is determined by the National Bank (Pro vnesennya zmin do deyakykh normatyvno-pravovykh aktiv Natsionalnoho banku Ukrayiny; Pro zatverdzhennya normatyvno-pravovykh aktiv Natsionalnoho banku Ukrayiny). In this case, under arbitration operations on terms of margin trading (hereinafter - arbitration operations) we understand non-cash transactions, which provide the fulfilment of two counter-obligations to buy and sell one foreign currency for another foreign currency and which are carried out without a real supply of currency in the international foreign exchange market in order 
to receive profit from changes in the exchange rate or hedging currency risks.

Terms of conducting arbitration operations between the bank and the client are specified in the agreement on the implementation of arbitration operations, including:

1) notification of the risks of conducting arbitration operations by the client's bank;

2) order of placement of the guarantee fee by the client (amount of the deposit, type of currency, term);

3) procedure for settlements between the bank and the client based on the results of arbitration operations (compensation of losses at the expense of the guarantee fee, the procedure for crediting profits);

4) frequency and procedure for providing information to the client about the transactions, which were performed by the client, the movement of his funds, and the balance of funds on his accounts (Pro vnesennya zmin do deyakykh normatyvno-pravovykh aktiv Natsionalnoho banku Ukrayiny; Pro zatverdzhennya normatyvno-pravovykh aktiv Natsionalnoho banku Ukrayiny).

The mentioned NBU's steps seem rather controversial. It is so, because, first of all, such an approach corresponds neither to any European practice in this area nor to Ukrainian legislation, especially the Law "On Financial Services and State Regulation of Financial Services Markets” 12.07.2001 No. 2664-III. In most European countries, the supervision of the operation of forex companies is carried out not by national banks, special financial commissions, management, committees, etc. (for example, in Germany - by the Federal Financial Control Agency, in Austria - by the Financial Markets Commission, in Estonia - by the Financial Control Office). If we talk about Ukrainian legislation, then in the Article 21 of the aforementioned law "On Financial Services and State Regulation of Financial Services Markets" it is clearly enshrined that the state regulation of financial services markets is carried out: in the market of banking services and money transfer activities - by The National Bank of Ukraine; in Securities and Derivatives (Derivatives) Markets - by the National Securities and Stock Market Commission. If we talk about other financial services markets - the national commission that carries out state regulation in the field of financial services markets. The Antimonopoly Committee of Ukraine and other state bodies make control over the activities of participants in financial services markets and receive information from them within the limits of the powers specified by law (Pro finansovi posluhy ta derzhavne rehulyuvannya rynkiv finansovykh posluh).

Secondly, not all forex companies operating in Ukraine belonged to the so-called "forex kitchens" and honestly fulfilled their obligations to their customers. The NBU having carried out the same transfer of the provision of forex services in the area of banking activity, and thus, made it impossible to operate within the framework of the legal field of forex companies, which do not have the status of banking institutions. Then the question arises about the correspondence of such a position of the NBU to the article 42 of the Constitution of Ukraine. The indicated activity (providing forex services) is business and at the same time, it is not directly prohibited by any law. However, in accordance with the mentioned NBU resolution, the subject (legal entity, individual entrepreneur) cannot be engaged in this type of business, if it does not have the status of a banking institution.

Thirdly, the steps taken by the NBU did not substantially strengthen the guarantees of the rights of private investors, and moreover, they did not contribute to the increase in tax revenue to the budget from the activities of forex companies. After all, the majority of forex companies in Ukraine that do not have the status of a banking institution are not residents of Ukraine and they are registered in offshore areas. It is obvious that such a situation does not contribute to hindering the outflow of capital from the country with the help of these companies, it does not provide a proper control over the legality of cash flows and, of course, it does not make investors of such forex brokers more secure, It is so because disputes between investors and forexbrokers are usually resolved far beyond the jurisdiction of Ukraine. That is, the ordinary Ukrainian citizens who have invested their funds in the Forex market through such foreign forex companies, in fact, do not have any legal means of real influence on these companies, in case if they have any claims to the brokers regarding the lawfulness, transparency, and conscientiousness of the fulfilment of their brokerage obligations to the client.

The mentioned circumstances indicate that in the question about the settlement of Forex, the NBU chooses the most simple and, obviously, not the most expedient and useful way. To our mind, in this question, we should take advantage of the EU experience and choose the way of not restricting access to making a business of providing forex services. It is necessary to establish clear and understandable requirements for the licensing of forex companies, to consolidate reliable guarantees of their clients' rights, and to introduce a quality control over the activities of such companies.

Thus, the main regulatory document regulating the activities of forex companies in the territory of the EU is Directive 2004/39/EC on Markets in Financial Instruments (MiFID). According to this legal act, companies that provide access to private investors to the Forex market are investment companies. At the same time, according to this Directive, investment services and (or) investment activities include such as: 1) acceptance and transfer of orders for one or more financial instruments; 2) execution of orders on behalf of clients; 3) making transactions on at own expense; 4) management of assets; 5) consultation on investment; 6) underwriting of financial instruments and/or placing them on a firm commitment basis; 
7) placement of financial instruments without firm commitments; 8) management of multilateral trading facilities Paskalova, Sibirianska, Maliarchuk, Pirnykoza, 2017).

The key question, on the settlement of which the specified Directive is directed, is to grant permission to engage in investment activities. So, firstly, when granting a license, the competent authorities must be sure of the positive nature of business reputation and sufficient experience in financial, in particular, investment and persons who will manage an investment company; and secondly, the company must have sufficient financial resources for the investment activity. The level of capital adequacy is determined by EU Directive 2006/49/ EC dated 06.14.2006 "On Capital Adequacy of Investment Firms and Credit Institutions”. According to this Directive, particularly, Article 9, companies that perform orders from investors on financial obligations, which include forex companies as well, must have an initial capital of at least 730000 EUR (Directive 2006/49/Ec of the European Parliament and of the CounciL of 14 June 2006 on the capital adequacy of investment firms and credit institutions). Thirdly, according to MiFID requirements, the investment firm must have stable, administrative and accounting procedures, internal control mechanisms, effective risk assessment procedures, and effective mechanisms for monitoring and information security systems. Fourthly, the activity of an investment firm should be transparent, first of all, which is shown, in its duty to provide the investor (client) with all necessary information about the grounds and conditions of the firm's operation at the stage of concluding the agreement with the client, as well as other information necessary for the client in the process of executing financial transactions on his behalf and/or on the results of their implementation. In particular, MiFID obliges Forex brokers to provide their customers with daily reports of their actions on their behalf. An important point is that the investment company itself must prove the adequacy and timeliness of providing information to the client, in case of a dispute between a client and an investment company and putting in relation to this the issue of customer awareness.

The MiFID sets common, most important requirements for the activities of investment companies, including forex companies. At the same time, each EU member country has the right to detail and develop the provisions of Directive 2004/39/EC (Commission Directive implementing Directive 2004/39/EC) at the national level. For example, each country independently determines, which authorities check the compliance of the company, which intends to obtain a license about investment activities, MiFID requirements, and, in fact, which authorities issue a license, as well as control the compliance of such companies with the norms of the current legislation, both EU and national. For example, in the Federal Republic of Germany, it is the Federal Financial Supervision Authority (BaFin), which is the main financial services market supervisor. In its activities, this body is controlled and accountable to the Federal Government. Besides, the Management, during the exercise of its supervisory and control powers, closely cooperates with the Federal Bank of Germany. Such status as The Federal Financial Supervision Authority is determined by the Federal Law on Financial Supervision Authority. During its work, the Management quite strictly control activities of forex companies by actively using its right to conduct sudden inspections. According to the results of inspections, in case of detection of violations, the Management has the right to impose fines on the company, the amounts of which may exceed 100 thousand euros. For example, in England, supervision over the activities of forex companies is carried out by the Financial Conduct Authority (FCA). Its powers include the licensing of forex brokers, oversight of the security of the financial system of the state and the compliance of financial rights of their clients by the listed companies.

We also consider it necessary to pay attention to such moment as self-regulation of activities of forex companies in Ukraine. A number of European countries, along with controlling regulatory authorities, monitor the legality, transparency, and conscientiousness of forex companies by self-regulatory organizations, which are created by the same companies. In Ukraine, in 2013, the Association "Ukrainian Centre for OTC Financial Instruments and Technologies Development" was established, which operates on the basis of the Charter of 01.07.2014. The subject of the Association's activity is the development, implementation, and monitoring of the application of unified standards and rules of activity of legal entities and individual entrepreneurs, whose activities include the provision of services by using information and communication technologies related to the operation of OTC financial instruments either in the international currency market (Forex) or in other markets. The mentioned activity includes the activities of: legal entities that provide operations to individuals and legal entities in the Forex market (hereinafter referred to as "Forex Companies"); legal entities, which attract clients for Forex Companies in order to obtain rewards from such clients, but which have no right to keep accounts of such clients, or accept money for them or other security and perform on their behalf transactions in the Forex market, but not limited by it (hereinafter - "Representatives of Forex Companies"); legal entities engaged in software development and maintenance; legal entities that develop and maintain the software, which is necessary for carrying out the activities specified in paragraph 4.1 of the Statute; legal entities that collect and provide financial news and other information, which is necessary for the activities specified in the paragraph 4.1 
of the Statute (Statut asotsiatsiyi «ukrayinskyy tsentr rozvytku pozabirzhovykh finansovykh instrumentiv i tekhnolohiy»). In its activities, this Association pursues a number of goals as: unification of the rules of behaviour (business practices) of individuals, who carry out entrepreneurial activity in the field, which is defined in paragraph 4.1 of the Statute; unification of rules of conclusion, execution, and responsibility for nonfulfilment and/or improper performance of agreements in the field specified in the paragraph 4.1 of the Statute; assistance in preventing property damage to legal entities, state or municipal property, as well as damage to the business reputation of legal entities obtained as a result of the guilty (inaction) of the members of the Association during the performance of activities in the field specified in paragraph 4.1 of the Statute; assistance in the reimbursement of damage, in case of intended infliction by members of the Association, due to shortcomings in the work and the provision of services, executed and provided by members of the Association; improvement of the quality of works and services, as well as the possible increase in the volume of services and work in the field specified in paragraph 4.1 of the Statute, as well as other types of activities carried out by members of the Association; carrying out an analysis of the activities of its members; etc. (Statut asotsiatsiyi «ukrayinskyy tsentr rozvytku pozabirzhovykh finansovykh instrumentiv i tekhnolohiy»).

Creation of such Association is, of course, a positive step towards regulating the functioning of the Forex market in Ukraine. But there is the problem that there are no powers that would allow it to actually exercise control in the specified area. All of its decisions are advisory. There is no guarantee that these recommendations will be taken into account by the market participants and/or by the corresponding government bodies. Besides, Ukrainian legislation does not oblige forex companies, which operate in the territory of our country, to join this Association.

\section{Conclusions}

Summarizing all the mentioned above, we can confidently state that in Ukraine, the Forex market operates in legal vacuum conditions, which negatively affects both the protection of rights of forex clients and the amount of tax revenues to the state budget. Taking into account the existing volumes and the growth rates of this market, we consider that the legislator should make appropriate amendments and additions to the current legislation, as soon as possible in order to regulate abovementioned branch of financial activity. In this case, the principles and requirements set out in the MiFID must be taken into account obligatorily. Besides, studying and borrowing of the experience of EU countries in regulating the activity of public authorities, which control the activities of forex companies, as well as the creation of a legal framework for the implementation of self-regulation of these companies, seem necessary and useful. It is necessary to abolish provisions allowing arbitration operations only to banking institutions. Instead, a special law should be adopted (or amendments to the current Law "On Financial Services and State Regulation of Financial Services Markets" should be made). This law should define clear and strict conditions and procedures about licensing Forex companies, as well as requirements for their activities, in particular: customer service, payment of taxes, interaction with state authorities, and participation in Forex trading company's self-regulation.

\section{References:}

Seliuchenko, N. Ye., Shmihelska, Z. K. (2012). Upravlinnya finansovoyu systemoyu Ukrayiny [Management of the financial system of Ukraine]. Visn. Nats. un-tu "Lviv. politekhnika", № 725, p. 366-371.

Rol, V. F., Serhiienko, V. V., Popova, S. M. (2011). Finansove pravo. Navch. posib. [ Finance law. Teaching manual]. K.: Tsentr uchbovoyi literatury, p. 392. (in Ukrainian)

Kravchuk, P. (2013). Problemy ta perspektyvy rozvytku finansovoyi systemy Ukrayiny [Problems and prospects of development of the financial system of Ukraine]. Ekonomichni nauky. Cer. : Oblik i finansy, p. 129-133. Retrieved from: http://nbuv.gov.ua/UJRN/ecnof_2013_10\%282\%29_18. (in Ukrainian)

Chernenko, L. V. Problemy finansovoyi systemy Ukrayiny v suchasnykh umovakh [Problems of the financial system of Ukraine in the current Terms]. Retrieved from: http://www.khntusg.com.ua/files/sbornik/vestnik_105/51. pdf (in Ukrainian)

Korol, M. M. (2015). Valyutnyy rynok Ukrayiny: stan, problemy y perspektyvy [The foreign exchange market of Ukraine: state, problems and prospects]. Stalyy rozvytok ekonomiky, № 3, p. 65-70. Retrieved from: http://nbuv.gov.ua/UJRN/sre_2015_3_10 (in Ukrainian)

Bozhydarnik, N. V. (2013). Valyutni operatsiyi pidruchnyk [Foreign exchange operations. textbook]. K: "Tsentr uchbovoyi literatury", 698 p. (in Ukrainian)

Starynskyy, M. V. (2012). Valyutnyy rynok yak finansovo-pravova katehoriya [Foreign exchange market as a financial and legal category]. Pidpryyemnytstvo, hospodarstvo i pravo, № 8, p. 67-70. (In Ukrainian)

Rohach, O. I., Filipenko, A. S., Shemet, T. S. (2003). Mizhnarodni finansy: Pidruchnyk [International finance: A textbook]. K: Lybid, 784 p. Retrieved from: http://pidruchniki.com/finansi/etapi_rozvitku_svitovoyi_ valyutnoyi_sistemi. (in Ukrainian) 
Patyka, N. I. (2012). Mizhnarodni valyutno-kredytni vidnosyny : navch. posib. [ International Monetary and Credit Relations: Teach. manual]. K.: Znannya, 566 p. Retrieved from: http://pidruchniki.com/1214031047636/ finansi/evolyutsiya mizhnarodnoyi valyutnoyi sistemi. (in Ukrainian)

Hrontkovska, H. E., Riaba, O. I., Ventsuryk, A. M., Krasnovska, O. I. (2014). Mizhnarodna ekonomika [tekst] : navch. posib.[ International Economics [text]: teaching manual]. Kyiv: «Tsentr uchbovoyi literatury», 384 p. Retrieved from: http://pidruchniki.com/1124052562553/ekonomika/mizhnarodna_valyutna_sistema. (In Ukrainian)

Kozak, Yu. H., Rzhepishevskyi, K. I., Kovalevskyi, V. V. (2004). Mizhnarodna ekonomika: v pytannyakh ta vidpovidyakh: Navchalnyy posibnyk [International Economics: Questions and Answers: teaching manual]. Kyiv:«Tsentr uchbovoyi literatury», 676 p. Retrieved from: http://pidruchniki.com/1202022451152/ ekonomika/v_chomu_polyagayut_sistema_zolotogo_standartu_bretton-vudska_valyutna_sistema. (In Ukrainian)

Chto takoe Foreks [What is Forex?]. Foreks Ukrayna -Forex Ukraine. Retrieved from: http://www.forexua.com/ $\mathrm{ru} /$ study/aboutforex.

Paskalova A., Sibirianska Yu., Maliarchuk L., Pirnykoza P. (2017). Mizhnarodnyy dosvid rehulyuvannya rynku Foreks [International experience in regulating the Forex market]. Ofis $\mathrm{z}$ finansovoho ta ekonomichnoho analizu $\mathrm{u}$ Verkhovniy Radi Ukrayiny, p. 33. (In Ukrainian).

Otchet po Foreks za peryod 2013-2016 ot Banka mezhdunarodnykh raschetov [Report on Forex for the period 2013-2016 from the Bank for International Settlements]. Retrieved from: https://justforex.com/blog/ru/ statistika-foreks/.

Holubchik, V.V. (2012). Problemni pytannya diyalnosti rynku foreks v Ukrayini [Problematic issues of Forex market activity in Ukraine]. Visnyk Natsionalnoho tekhnichnoho universytetu Ukrayiny "Kyyivskyy politekhnichnyy instytut". Politolohiya. Sotsiolohiya. Pravo, 3, p. 170-174. - Retrieved from: http://nbuv.gov.ua/UJRN/VKPI soc_2012_3_33. (In Ukrainian)

Obsyahy rynku forex v Ukrayini syahayut $40 \mathrm{mln}$ dolariv [The volumes of the forex market in Ukraine reach 40 million dollars]. Retrieved from: http://vkurse.ua/ua/business/obemy-rynka-forex-v-ukraine.html. (In Ukrainian) Vyhody ta ryzyky instytualizatsiyi rynku Foreks v Ukrayini [Benefits and risks of institutionalization of the Forex market in Ukraine]. IA «Interfax-Ukrayina». Retrieved from: http://ua.interfax.com.ua/news/pressrelease/171723.html.

Pro vnesennya zmin do deyakykh normatyvno-pravovykh aktiv Natsionalnoho banku Ukrayiny : Postanova Pravlinnya NBU vid 3.08. 2012 r. \# 327 [On amendments to certain legal acts of the National Bank of Ukraine: Resolution of the Board of the NBU dated 3.08. 2012 number 327]. Retrieved from: http://zakon0.rada.gov.ua/ laws/show/z1434-12

Pro zatverdzhennya normatyvno-pravovykh aktiv Natsionalnoho banku Ukrayiny : Postanova Pravlinnya NBU vid 10.08.2005 \# 281 [On approval of legal acts of the National Bank of Ukraine: Resolution of the Board of the NBU dated August 10, 2005 No. 281]. Retrieved from: http://zakon0.rada.gov.ua/laws/show/z0950-05.

Pro finansovi posluhy ta derzhavne rehulyuvannya rynkiv finansovykh posluh : Zakon Ukrayiny vid 12.07.2001 r. \# 2664-III [On Financial Services and State Regulation of Financial Services Markets: Law of Ukraine dated 12.07. 2001 No. 2664-III]. Vidomosti Verkhovnoyi Rady Ukrayiny (VVR), 2002, \# 1, st. 1.

Commission Directive implementing Directive 2004/39/EC of the European Parliament and of the Council as regards organisational requirements and operating conditions for investment firms, and defined terms for the purposes of that Directive. Retrieved from: http://ec.europa.eu/internal_market/securities/docs/isd/dir-200439-implement/dir-6-2-06 final en.pdf

Directive 2006/49/Ec of the European Parliament and of the CounciL of 14 June 2006 on the capital adequacy of investment firms and credit institutions (recast). Retrieved from: http://eur-lex.europa.eu/legal-content/EN/ ALL/?uri=CELEX:32006L0049 (In Ukrainian)

Statut asotsiatsiyi «ukrayinskyy tsentr rozvytku pozabirzhovykh finansovykh instrumentiv i tekhnolohiy» vid 01.07.2014 r. [Statute of the Association "Ukrainian Center for the Development of OTC Financial Instruments and Technologies" dated 01.07.2014]. Retrieved from: http://ucrfin.com.ua/wp-content/uploads/2014/01/ UCRFIN_New_Statute.pdf(In Ukrainian) 